\title{
Diagnóstico de Scrapie no estado do Rio de Janeiro: relato de caso
}

Mario Felipe Alvarez Balaro ${ }^{[a]}$, Isabel Oliveira Cosentino ${ }^{[a]}$, Edviges Maristela Pituco ${ }^{[b]}$, Alessandra Figueiredo de Castro Nassar ${ }^{[b]}$, Aerlem Cynnara Silva Vieira ${ }^{[c]}$, Ana Karina Cunha Callado ${ }^{[c]}$, Maria do Carmo Custódio de Souza Hunold Lara ${ }^{[b]}$, Eliana Cassaro Monteforte Villalobos ${ }^{[b]}$, Felipe Zandonadi Brandão $0^{[a]}$, Claudia Del Fava ${ }^{[b]}$

\footnotetext{
[a] Faculdade de Veterinária, Universidade Federal Fluminense (UFF), Niterói, RJ, Brasil

[b] Instituto Biológico, Agência Paulista de Tecnologia dos Agronegócios (APTA), São Paulo, SP, Brasil

${ }^{[c]}$ Laboratório Nacional Agropecuário em Pernambuco (LANAGRO/PE), Recife, PE, Brasil
}

*Autor correspondente

e-mail: mariobalaro@hotmail.com

\section{Resumo}

Objetiva-se a descrição de caso clínico neurológico em ovino com diagnóstico complementar de scrapie. Um carneiro da raça Dorper ,com 4,5 anos, mantido em confinamento junto a outro macho, apresentou histórico (evolução de duas semanas) de perda de peso e ausência de vocalização ao arraçoamento. No exame clínico, constatou-se prostração, ataxia moderada associada à fraqueza nos quatro membros, discreto cambaleio nos posteriores, silêncio auscultatório nos lobos craniais do pulmão e estertor no lobo diafragmático esquerdo. Não foram detectadas alterações no hemograma e apenas uma discreta hipoproteinemia $(5,9 \mathrm{~g} / \mathrm{dL})$ associada à hipoalbuminemia $(2,1 \mathrm{~g} / \mathrm{dL})$ na bioquímica sérica. 0 animal foi medicado durante sete dias com enrofloxacina (5 mg/kg) e cinco dias com fenilbutazona (10 mg/kg). Junto à irresponsividade ao tratamento, verificou-se piora na condição física, mantença dos ruídos adventícios pulmonares e, no quadro locomotor com ataxia, assinergia, titubeação, tremores no reflexo de membro posterior, reflexo de pêndulo nos membros anteriores, astenia e hipotonia muscular. Em decorrência da perda de peso e a pedido do proprietário, foi realizada a eutanásia do animal. Na necropsia verificou-se enfisema nos lobos craniais e médios do pulmão. 0 lobo diafragmático esquerdo possuía áreas difusas de congestão na superfície e ao corte. Constatou-se ligeira hepatomegalia com congestão difusa e coloração levemente amarronzada do fígado. Na análise microscópica, observou-se colangiohepatite não purulenta, glomerulonefrite, edema e congestão pulmonar e hemossiderose. O SNC apresentou as seguintes alterações: medula espinhal cervical com hematoma subdural; óbex com discreto manguito perivascular mononuclear e discretos focos hemorrágicos no neurópilo, além de discreto infiltrado inflamatório mononuclear meníngeo 
e congestão meníngea; córtex cerebral frontal, parietal, temporal, occipital e diencéfalo apresentavam edema e congestão cortical com congestão meníngea. Tais achados foram sugestivos de meningoencefalite não purulenta inespecífica. Dentre os exames complementares, verificou-se a presença de Staphylococcus intermedius e Bacillus sp. na cultura de bactérias aeróbias a partir de fragmentos pulmonares. Segmentos do SNC foram negativos para raiva (imunofluorescência), língua azul (PCR), toxoplasma e neospora (PCR). Igualmente, um fragmento do óbex enviado ao LANAGRO/PE para diferencial de enfermidades priônicas foi positivo na detecção de proteína priônica pela imunohistoquímica (IHQ). A partir dos achados, acredita-se que um possível traumatismo cervical (oriundo de confronto entre machos) e lesão medular tenha sido o responsável pela evolução na sintomatologia neurológica, associada à dor e perda de peso, tendo sido incidental o diagnóstico de Scrapie, uma vez que não foram observadas alterações espongiformes no tronco encefálico. No Brasil, o Scrapie foi diagnosticado pela primeira vez em 1978 e, desde então, já foram feitos relatos nos Estados do MS, RS, PR, MG, SP e BA, sendo este o primeiro caso no estado do RJ. Assim, ratificase a importância do diagnóstico diferencial de síndromes neurológicas associado ao sistema nacional de vigilância de encefalopatias espongiformes transmissíveis no Brasil. 